\title{
IMPLEMENTASI PROGRAM PEMBERDAYAAN EKONOMI RAKYAT MELALUI PROGRAM MAMANGUN TUNTANG MAHAGA LEWU (PM2L) \\ (Studi Kasus di Dua Desa Tertinggal di Kalimantan Tengah)
}

\author{
Karlina Batik, Agus Suman dan Asfi Manzilati \\ karlinabatik@ymail.com \\ Fakultas Ekonomi dan Bisnis Universitas Barawijaya Malang \\ Jl. Mayjen Haryono 169, Lowokwaru, Malang 65145, Jawa Timur
}

\begin{abstract}
This study aims to determine the implementation of the program of economic empowerment of the people through the program mamangun Tuntang mahaga Lewu (PM2L). Writing method used is qualitative. This method was chosen because it examines the phenomenon of something in more depth, and more able to understand the phenomenon that until now has not been known. Through this study were obtained in the implementation of key information that PM2L are several stages to go through the stage of coordination, socialization, implementation of the action, coaching, monitoring and evaluation. In general, the stages through which it has not been optimal program implementation in practice, especially in terms of stages of development.
\end{abstract}

Keywords: PM2L, Economic Empowerment of the People, Implementation of Program

\begin{abstract}
ABSTRAK
Penelitian ini bertujuan untuk mengetahui implementasi program pemberdayaan ekonomi rakyat melalui program mamangun tuntang mahaga lewu (PM2L). Metode penulisan yang digunakan adalah kualitatif. Metode ini dipilih karena meneliti fenomena atas sesuatu secara lebih mendalam, dan lebih dapat memahami fenomena tersebut yang sampai sekarang belum banyak diketahui. Melalui penelitian ini diperoleh informasi kunci bahwa dalam implementasi PM2L terdapat beberapa tahapan yang harus dilalui yaitu tahapan koordinasi, sosialisasi, penerapan aksi, pembinaan, monitoring dan evaluasi. Secara garis besar tahapan-tahapan yang dilalui dalam implementasi program belum optimal dalam pelaksanaannya, terlebih dalam hal tahapan pembinaan.
\end{abstract}

Kata Kunci : PM2L, Pemberdayaan Ekonomi Rakyat, Implementasi Program

\section{PENDAHULUAN}

Seiring dengan berubah, dimana sistem

diberlakukannya otonomi daerah, pemerintahan yang dulunya bersifat keadaan sistem pemerintahanpun sentralistik kemudian sebagian 
dialihkan ke sistem yang bersifat desentralistik. Otonomi daerah telah memberikan peluang yang lebih luas dan leluasa kepada daerah untuk dapat berkreasi dan berinovasi membuat suatu kebijakan pemerintah daerah yang disesuaikan dengan kondisi dan kebutuhan masyarakat lokal. Dengan demikian, pemerintah daerah dapat mengejar ketertinggalannya dalam berbagai hal, tidak terkecuali dalam upaya pengentasan kemiskinan, terutama pada masyarakat desa tertinggal yang perlu mendapatkan penanganan secara serius dan terencana. Akselerasi dalam penanganan desa tertinggal perlu dilaksanakan secara serius dikarenakan banyak desa yang masih mengalami ketertinggalan di berbagai faktor baik, dari segi ketimpangan pendapatan maupun keterbatasan wilayah.

Dari berbagai provinsi yang ada di Indonesia, Provinsi Kalimantan Tengah merupakan salah satu provinsi di Indonesia yang harus diperhatikan karena mempunyai ketimpangan pendapatan yang berimbas pada kemiskinan. Hal yang perlu disoroti dari kondisi tersebut adalah penduduk miskin di
Kalimantan Tengah lebih banyak berada di desa-desa terpencil yang akses jangkauannya sangat minim. Dari 1.448 desa/kelurahan yang ada di Kalimantan Tengah, 978 desa atau $72,12 \%$ diantaranya merupakan desa/kelurahan tertinggal dan cenderung terisolasi.

Berangkat dari kondisi tersebut, sejak tahun 2008 Pemerintah Daerah Kalimantan Tengah telah menetapkan suatu kebijakan yang dituangkan dalam suatu program pemberdayaan masyarakat yang diberi nama Program Mamangun Tuntang Mahaga Lewu (PM2L). Istilah Mamangun Tuntang Mahaga Lewu diambil dari bahasa dayak ngaju Kalimantan Tengah. Mamangun artinya membangun, mahaga artinya menjaga dan lewu artinya desa. PM2L merupakan program Pemerintah Daerah Kalimantan Tengah untuk membangun desa tertinggal yang mensinergiskan dua bentuk perencanaan, yaitu antara perencanaan top down dan bottom up.

Dalam PM2L terdapat 5 (lima) prioritas pembangunan yang telah dirumuskan sesuai dengan 
permasalahan daerah seperti yang termuat dalam Laporan Pemerintah Provinsi Kalimantan Tengah pada tahun 2008, yaitu pembangunan bidang prasarana dasar, pembangunan bidang peningkatan akses masyarakat terhadap pendidikan, pembangunan bidang peningkatan akses masyarakat terhadap kesehatan, pembangunan bidang pemberdayaan ekonomi rakyat, dan pembangunan bidang pemberdayaan masyarakat. Dari program-program tersebut, untuk menunjang strategi sumber daya manusia (SDM) dan ekonomi masyarakat daerah yang tertinggal, pembangunan utama yang perlu diprioritaskan adalah melalui pemberdayaan ekonomi rakyat. Keputusan prioritas tersebut dikarenakan program pemberdayaan ekonomi rakyat memiliki jangkauan yang paling luas, dalam artian bahwa masyarakat dapat secara langsung terlibat dalam kegiatan-kegiatan pembangunan dan dapat memanfaatkan serta menikmati hasilhasil pembangunan. Program pemberdayaan ekonomi rakyat yang dimaksudkan disini adalah bantuan penguatan pemerintah dalam bentuk modal usaha atau barang modal dan pendampingan yang disalurkan oleh Instansi terkait. Program ini merupakan program yang langsung menyentuh kondisi riil masyarakat setempat dan melibatkan masyarakat lokal (desentralistik) dalam perencanaan (bottom up planning) maupun dalam pelaksanaannya.

Namun dalam pelaksanaannya, masih terdapat banyak permasalahan dan hambatan yang terjadi. Desa Bagendang Tengah Kecamatan Mentaya Hilir Utara Dan Desa Kandan Kecamatan Kota Besi Kabupaten Kotawaringin Timur merupakan dua desa yang dapat menggambarkan kondisi desa tertinggal di Kalimantan Tengah yang dapat dijadikan tolok ukur dalam pelaksanaan atau implementasi Program PM2L. Dari dua desa tersebut diharapkan gambaran maupun permasalahan yang terjadi terkait implementasi PM2L dapat terlihat sehingga perbaikan PM2L dapat dilakukan dengan tepat.

\section{Konsep Pemberdayaan}

Konsep pemberdayaan menurut versi birokrasi pemerintah lebih ditekankan pada pemberdayaan 
ekonomi. Di sisi lain, Randy \& Riant

mendefinisikan

pemberdayaan adalah sebuah "proses

menjadi", bukan sebuah "proses instant". Sebagai proses, pemberdayaan mempunyai tiga tahapan: penyadaran, pengapasitasan, dan pendayaan. Tahap pertama adalah penyadaraan, yaitu dalam tahap ini target yang hendak diberdayakan diberi "pencerahan" dalam bentuk pemberian penyadaran bahwa mereka mempunyai hak untuk mempunyai sesuatu. Tahap kedua adalah pengkapasitasan yang sering disebut "capacity building", atau dalam bahasa yang lebih sederhana memampukan atau enabling. Untuk diberikan daya atau kuasa, yang bersangkutan harus mampu terlebih dahulu. memampukan manusia, baik dalam konteks individu maupun kelompok. Tahap ketiga adalah pendayaan yakni proses pemberian daya atau kekuasaan diberikan sesuai dengan kecakapan penerima.

Rubin dalam Sumaryadi
(2005) mengemukakan 5 prinsip
dasar dari konsep pemberdayaan
masyarakat sebagai berikut:

1. Pemberdayaan masyarakat memerlukan break-even dalam setiap kegiatan yang dikelolanya, meskipun orientasinya berbeda dari organisasi bisnis, dimana dalam pemberdayaan masyarakat keuntungan yang diperoleh didistribusikan kembali dalam bentuk program atau kegiatan pembangunan lainnya.

2. Pemberdayaan masyarakat selalu melibatkan partisipasi masyarakat baik dalam perencanaan maupun pelaksanaan yang dilakukan.

3. Dalam melaksanakan program pemberdayaan masyarakat, kegiatan pelatihan merupakan unsur yang tidak bisa dipisahkan dari usaha pembangunan fisik.

4. Dalam implementasinya, usaha pemberdayaan harus dapat memaksimalkan sumber daya, khususnya dalam hal pembiayaan baik yang berasal dari pemerintah, wasta maupun sumber-sumber lainnya.

Kegiatan pemberdayaan masyarakat harus dapat berfungsi sebagai penghubung antara kepentingan pemerintah yang bersifat makro dengan kepentingan masyarakat yang bersifat mikro. 
Proses pemberdayaan bisa dimaknai sebagai runtutan perubahan dalam perkembangan usaha untuk membuat masyarakat menjadi lebih berdaya. Wilson (1996) memaparkan empat tahapan dalam proses pemberdayaan, yaitu penyadaran (Awakening), pemahaman

(Understanding), pemanfaatan (Harnessing), dan penggunaan (Using).

Pemberdayaan juga sangat berhubungan dengan partisipasi masyarakat lokal. Usman (2003) menjelaskan bahwa dalam pengertian terminologis, pemberdayaan dapat didefinisikan sebagai "upaya untuk mengaktualisasikan potensi yang sudah dimiliki oleh masyarakat". Dalam konteks ini, secara implisit pemberdayaan mengandung unsur "partisipasi” yang seharusnya dimunculkan dari dalam diri masyarakat itu sendiri.

Prinsip Dasar PM2L sebagai Program Pemerintah Kalimantan

\section{Tengah}

Dalam PM2L, pendekatan implementasi dari model program adalah melalui 5 prinsip dasar yaitu: 1) Prinsip Basic Need, dimana kegiatan disusun benar-benar berdasarkan kebutuhan desa, untuk itu profil desa masing-masing lokasi PM2L yang memuat tentang berbagai hal terkait dengan masalah ketertinggalan desa yang akan ditangani; 2) Prinsip Partisipatif, dimana proses perencanaannya melibatkan masyarakat. Kepala desa dilibatkan secara langsung untuk membahas secara bersama-sama tentang rencana aksi yang akan dilaksanakan di desa masing-masing; 3) Prinsip Sinergisitas, untuk pelaksanaan PM2L dilengkapi dengan dokumen Rencana Aksi yang memuat secara komprehensip tentang seluruh aktivitas, besarnya dana, kapan pelaksanaannya, dan siapa yang bertanggung jawab dari SKPD yang terlibat; 4) Prinsip Pemberdayaan, yaitu sebagaimana halnya program-program pemberdayaan, PM2L dilengkapi dengan tenaga pendampingan masyarakat di lapangan, dalam hal ini pemerintah daerah mengangkat Sarjana (SM2L) sebagai pendamping PM2L; 5) Prinsip Refocusing, dimana dalam seluruh aktivitas PM2L diarahkan dan terfokus pada 14 variabel penyebab ketertinggalan desa, fokus pada 5 program prioritas 
dan fokus pada 3 desa terpilih per kabupaten/kota setahun.

\section{METODE PENELITIAN}

Metode penelitian yang digunakan adalah penelitian kualitatif dengan jenis pendekatan fenomenologi. Menurut Moleong (2006:6) Penelitian kualitatif itu sendiri bermaksud memahami fenomena tentang apa yang dialami oleh subjek penelitian, misalnya: perilaku, persepsi, motivasi, tindakan, dan lain-lain secara holistik, dan dengan cara deskripsi dalam bentuk kata-kata dan bahasa, pada suatu konteks khusus yang alamiah dan dengan memanfaatkan berbagai metode alamiah.

\section{PEMBAHASAN}

\section{Koordinasi; Sebagai Upaya Sinkronisasi Kegiatan}

Salah satu tahapan yang harus dilalui dalam penyelenggaraan PM2L adalah rapat koordinasi. Sebagai langkah awal untuk menunjang pelaksanaan program kegiatan PM2L supaya dapat terkoordinir dengan baik, maka sebelumnya dilakukan rapat koordinasi pertama yang dilaksanakan pada bulan September 2007 dengan mengundang bupati/walikota beserta segenap jajarannya.

Berbagai kalangan awalnya banyak yang mempertanyakan, bagaimana mungkin PM2L tersebut bisa dilaksanakan, sementara proses perencanaan pembangunan telah sampai pada tahap penetapan APBD. Akan tetapi PM2L bukanlah program baru yang membutuhkan pembiayaan baru, namun PM2L adalah sebuah model pendekatan pembangunan yang mensinergiskan dan memfokuskan seluruh sumber daya pembangunan melalui 3 (tiga) desa percontohan per kabupaten per tahun, guna membangun kemandirian masyarakat dalam membangun desa dan mempercepat pengentasan desa tertinggal di Kalimantan Tengah. Untuk itu, perlu dilakukan rapat koordinasi pertama untuk memantapkan pelaksanaan PM2L yang awal tahun 2008. Rapat koordinasi tersebut dikoordinir oleh salah satu SKPD (setuan Kerja Perangkat Daerah) yaitu BAPPEDA (Badan Perencanaan Pembangunan Daerah) Provinsi Kalimantan Tengah. Dalam mengemban 
tugasnya, pihak BAPPEDA hanya bertugas untuk menyinkronkan dan mensinergiskan kegiatan SKPD yang terlibat. Perlu diketahui bahwa pelaksanaan PM2L dikerjakan bersama oleh pemerintah provinsi dan pemerintah kabupaten/kota dengan mensinergikan dan memfokuskan seluruh sumberdaya. Ada dua level sinergi yang hendak dibangun melalui PM2L: pertama, sinergi antar level pemerintahan, mulai dari level provinsi, kabupaten/kota, kecamatan dan desa/kelurahan. Kedua, berkaitan dengan upaya memadukan program sektoral yang dijalankan oleh SKPD di setiap level pemerintahan.

Dalam rapat tersebut dilakukan pembahasan dan penghimpunan rencana-rencana aksi apa saja yang akan dijadikan kegiatan oleh semua SKPD yang ada di Provinsi dan Kabupaten/Kota. Harapannya, supaya kegiatan yang akan dilaksanakan menjadi sinkron dan bersinergi, sehingga tidak ada kegiatan SKPD yang tumpang tindih dalam satu desa. Maksud dan tujuan dari dilakukan rapat koordinasi tersebut nantinya akan menghasilkan Dokumen Rencana Aksi Bersama. Di dalam rapat tersebut masing-masing SKPD diharapkan berpartisipasi untuk mengalokasikan kegiatan yang dituangkan dalam rencana aksi supaya setiap kegiatan dapat dilaksanakan di lokasi PM2L yang sudah ditentukan pada tahun 2008. Sementara itu, desa yang menjadi lokasi PM2L itu dibangun secara berkeroyokan oleh SKPD yang terlibat.

Pembangunan desa dilakukan secara berkeroyokan artinya, semua SKPD yang terlibat secara bersamasama mengalokasikan anggaran dan kegiatan di desa tersebut dengan tujuan agar semua kebutuhan desa dapat secara langsung dipenuhi, sehingga pembangunan yang dilakukan di desa lokasi PM2L tidak setengah-setengah dalam implementasinya. Melakukan kegiatan secara berkeroyokan mengartikan juga bahwa tiap SKPD harus terpadu dan bersinergi dalam melakukan kegiatan PM2L, salah satunya dengan cara berkoordinasi dengan SKPD-SKPD yang terlibat. Namun faktanya, kegiatan yang dilaksanakan oleh SKPD yang terlibat belum sinkron, terpadu atau terkoordinir dengan baik dan belum 
bersinergis baik antara SKPD provinsi dan SKPD kabupaten maupun antar SKPD yang melaksanakan kegiatan yang sifatnya sejenis.

\section{Berdasarkan}

temuan

diketahui bahwa belum sinkron dan terpadunya kegiatan antar SKPD tersebut dapat dilihat ketika mereka (SKPD) memprogramkan kegiatan yang masuk ke dokumen rencana aksi bersama. Kegiatan SKPD yang masuk ke dalam dokumen rencana aksi, dimana kegiatan yang masuk ke dalam dokumen rencana aksi tersebut merupakan kegiatan wajib dari masing-masing SKPD. Dalam pelaksanaannya kegiatan tersebut dilaksanakan secara sendiri-sendiri dan masih menonjolkan ego sektoral, padahal kegiatan yang dilaksanakan merupakan kegiatan yang sejenis dan bisa dijalankan secara bersama-sama atau dengan kata lain bisa saling menopang dan mendukung antar SKPD satu dengan yang lainnya baik dari segi anggaran maupun kegiatan. Hal ini dilakukan untuk menyelesaikan persoalan yang selama ini terjadi terkait dengan keterbatasan anggaran, kewenangan pembinaan, dan sinkronisasi kegiatan. Saling menopangnya kegiatan antar SKPD dalam menjalankan satu kegiatan yang sama bukan berarti kegiatan yang dilaksanakan tersebut menjadi tumpang tindih antar SKPD, namun sebaliknya kegiatan tersebut akan menjadi bersinergi.

Terkait dengan menghindari tumpang tindihnya kegiatan, bukan berarti setiap SKPD yang menjalankan kegiatan yang sifatnya sejenis tidak boleh melakukan kegiatan yang sama, namun lebih kepada menggabungkan pelaksanaan kegiatan yang sama tersebut oleh beberapa SKPD berdasarkan pembagian perannya dan jenis kegiatan apa yang akan diplotkan dalam anggaran kegiatan. Dengan demikian bersinerginya kegiatan yang dilakukan oleh SKPD yang menjalankan kegiatan yang sejenis akan tewujud apabila diantara SKPD tersebut mempunyai persepsi yang sama tentang PM2L, saling berbagi peran untuk menyukseskan kegiatan yang sama, mampu menterjemahkan tugas pokok dan fungsi instansinya secara benar, melakukan sharing anggaran dalam kegiatan yang sama, memperjelas kewenangan dalam 
pembinaan baik antar SKPD propinsi dan SKPD kabupaten, maupun antar SKPD yang menjalankan kegiatan yang sejenis.

Menyangkut kewenangan masing-masing pemangku kepentingan dalam rapat koordinasi, belum ada kejelasan mengenai hirarkis pembagian kewenangan semua pihak yang terlibat ketika melakukan koordinasi. Sebenarnya rapat koordinasi tersebut merupakan wahana yang digunakan untuk memperjelas atau mempertegas pembagian kewenangan antar SKPD baik oleh SKPD provinsi maupun kabupaten, kades, dan camat setempat agar tidak terjadi kebingungan. Selain itu juga untuk menghindari saling lempar tanggung jawab antar SKPD dan menghindari tumpang tindihnya pelaksanaan tupoksi SKPD dalam menangani kegiatan yang sifatnya sejenis.

Disamping belum mantapnya koordinasi dalam pelaksanaan PM2L, hal lain yang mempengaruhi kurang optimalnya pelaksanaan PM2L yaitu menyangkut masih minimnya pemahaman aparat pemerintahan (SKPD) yang terlibat tentang program PM2L, baik di tingkat Provinsi maupun Kabupaten, juga keterpaduan dan sinergitas program dari tiap SKPD yang belum terwujud dikarenakan ketidaksepahaman antar SKPD.

Berdasarkan hasil temuan diketahui bahwa rapat koordinasi yang dilakukan dalam membahas perencanaan dan penganggaran PM2L belum sampai mengarah kepada penggabungan kegiatan yang akan dilakukan oleh SKPD, padahal kegiatan yang dilakukan di lokasi yang sama, kegiatan yang diprogramkan juga mempunyai kemiripan atau sejenis, namun secara tupoksi setiap SKPD mempunyai tupoksi yang berbeda-beda (Program kegiatan SKPD dapat dilihat pada hasil dan pembahasan sub bab implementasi kegiatan selanjutnya). Untuk itu diperlukannya koordinasi yang lebih baik antar SKPD dan masyarakat, demikian juga setiap aparat yang terlibat lebih memahami tupoksi bidang tugas instansinya masing-masing sesuai dengan kewenangan yang dimilikinya sehingga tidak terjadi saling mengambil fungsi instansi yang terlibat, sebab semakin mantapnya koordinasi program pemberdayaan 
ekonomi rakyat yang dilakukan oleh setiap SKPD dan masyarakat yang menangani kegiatan yang sifatnya sejenis, maka semakin mantap pula sinergisitas upaya pengentasan kemiskinan melalui pemberdayaan ekonomi rakyat perdesaan.

Sosialisasi; Hanya Sampai Pada Level Pemerintah Desa dan Belum ke Masyarakat Sasaran

Salah satu bentuk penyampaian informasi program kepada masyarakat adalah melalui sosialisasi. Pentingnya sosialisasi dalam pelaksanaan kegiatan agar terciptanya persepsi atau pemahaman yang sama antara pemerintah yang dalam hal ini SKPD dan masyarakat selaku penerima kegiatan. Dalam pelaksanaan sosialisasi ini terlebih dahulu dilakukan dengan melakukan rapat koordinasi.

Berdasarkan hasil temuan bahwa sosialisasi yang dilakukan selama ini hanya sampai di tingkat kabupaten saja yaitu dilaksanakan di ibukota kabupaten dengan mengundang pihak SKPD yang terlibat, camat dan kepala desa. Dan untuk mensosialisasikan kegiatan setiap SKPD yang masuk ke desa yang menjadi lokasi PM2L selanjutnya diharapkan dilakukan oleh masing-masing kepala desa. Kegiatan sosialisasi ini dikoordinir oleh pihak BAPPEDA provinsi dengan SKPD yang terlibat sebagai anggota tim sosialisasi. Adapun penyebab dari pelaksanaan sosialisasi PM2L yang hanya dilakukan di Ibukota Kabupaten saja dikarenakan oleh faktor anggaran. Dengan melihat kenyataan tersebut bahwa tidak semua unsur elemen masyarakat dilibatkan dalam sosialisasi, sehingga hal inilah yang menyebabkan belum optimalnya pelaksanaan PM2L karena yang ditugaskan untuk mensosialisasikan kepada masyarakat bawah atau penerima sasaran program, bukan orang teknisnya melainkan diserahkan kepada kepala desa yang punya wilayah yang belum tentu mempunyai pengetahuan teknis di bidang program kegiatan SKPD.

Petugas atau staf yang ditugaskan untuk ikut serta dalam sosialisasi pelaksanaan PM2L adalah orang yang belum tepat dan terpilih dalam artian orang yang terlibat seharusnya memang orang yang mempunyai tanggung jawab penuh dalam pelaksanaan tugas, mengerti 
dan memahami bidang tugasnya serta mempunyai kemampuan untuk berkoordinasi dengan pihak-pihak yang mempunyai keterkaitan dalam pelaksanaan kegiatan. Hal ini perlu diperhatikan dengan seksama untuk menjamin suksesnya pelaksanaan program kegiatan yang berkaitan dengan memberdayakan ekonomi masyarakat.

Berdasarakan atas temuan, dapat dikatakan bahwa keberhasilan program kegiatan yang terintegrasi dalam PM2L terkait pelaksanaan sosialisasi tergantung kepada beberapa faktor yaitu: lokasi sosialisasi, ketersediaan anggaran, kemampuan sumber daya manusia, dan faktor lembaga yang terlibat dalam sosialisasi. Tingkat keberhasilan program salah satunya ditentukan oleh aparat pelaksana program seperti halnya hasil penelitian yang dilakukan oleh Banteng (2004) yang menunjukkan bahwa tingkat keberhasilan dari pelaksanaan Program Pemberdayaan Ekonomi masyarakat Pesisir (PEMP) dipengaruhi secara signifikan oleh faktor sumberdaya manusia, faktor komunikasi, faktor sikap aparat pelaksananya dan faktor karakteristik kelembagaannya.

\section{Penerapan Aksi; Terjadi \\ Penyimpangan terhadap Aturan}

Tahap implementasi menentukan apakah kebijakan yang ditempuh oleh pemerintah benarbenar aplikabel di lapangan dan berhasil untuk menghasilkan output dan outcomes seperti yang telah direncanakan. Berkaitan dengan implementasi aksi program kegiatan PM2L, berdasarkan dokumen rencana aksi terdapat beberapa SKPD yang terlibat dalam aksi program pemberdayaan ekonomi rakyat melalui PM2L. Implementasi tersebut menggambarkan bagaimana praktek pelaksanaan kegiatan di lapangan baik yang dilakukan oleh SKPD yang terlibat maupun masyarakat yang menjadi sasaran program.

Menyangkut pelaksanaan aksi, terdapat beberapa temuan yaitu bahwa dalam penerapan aksinya dikembalikan kepada masing-masing SKPD sesuai dengan tupoksi yang dimilki dan tentunya kegiatan tersebut sudah tertuang dalam rencana aksi bersama. Sementara itu, menyangkut faktor penghambat 
pelaksana kegiatan bahwa sering terjadi bongkar pasang pelaksana di tahun berjalan, penyampaian laporan kegiatan mayoritas SKPD hanya berdasarkan atas prinsip "asal bapak senang", tidak diikuti dengan laporan yang sesungguhnya. Dalam arti, laporan yang disampaikan hanya sebagai formalitas saja yang notabene isinya hanya melaporkan prosentase realisasi fisik dan serapan anggaran kegiatan tahun berjalan namun belum sepenuhnya menyampaikan pokok permasalahan yang terjadi dalam operasional program kegiatan menyangkut hasil dan kebermanfaatan progam kegiatan kepada masyarakat sasaran program. Sehingga hasil pelaksanaannya tidak sesuai dengan target yang seharusnya dicapai, yaitu mampu meningkatkan taraf hidup masyarakat baik dari sisi peningkatan pendapatan dan tabungan, mampu menumbuhkan lapangan usaha baru, meningkatkan harkat dan martabat atas dasar persamaan akan hak dan kewajiban selaku warga negara, dan memenuhi asupan gizi bagi keluarga binaan.

Dikatakan demikian karena praktek pelaksanaan kegiatan di lapangan, baik yang dilakukan oleh
SKPD yang terlibat maupun masyarakat yang menjadi sasaran program tidak berjalan dengan baik, walaupun secara juklak dan juknis acuan laporannya jelas, namun terjadi ketidaksesuaian dalam prakteknya di masyarakat. Hal tersebut terindikasi dari : (1) Sebagian bantuan tidak tepat sasaran; (2) bantuan kurang berkualitas dan jenisnya tidak sesuai dengan kebutuhan dan kemampuan penerima; (3) paket tidak diikutii oleh pembinaan teknis oleh SKPD; (4) kurang lengkapnya jenis bantuan yang diberikan terutama bagi penumbuhan ekonomi baru; (5) bantuan yang difasilitasi oleh SKPD dianggap diberikan cuma-cuma saja oleh penerima, sehingga tidak ada tanggung jawab mereka untuk menjalankan supaya bisa berkembang; dan (6) kegiatan tidak dilaksanakan secara berkelompok oleh masyarakat penerima, melainkan secara individu. Disamping itu terdapat temuan lainnya yaitu bantuan modal yang sifatnya uang tunai dipandang belum cukup, namun untuk bantuan yang lain sudah dipandang cukup oleh sebagian penerima. Jumlah anggota 
dalam satu kelompok terlalu banyak, dan ketika barang bantuan didistribusikan tidak didampingi oleh SKPD pemilik program kegiatan.

Dengan tidak dijalankannya kegiatan secara berkelompok, namun dilakukan secara individu mengakibatkan salah satu pendekatan untuk memberdayakan masyarakat melalui pemberian bantuan yang sifatnya stimulus tidak terpenuhi. Hal tersebut terjadi karena diantara masyarakat penerima bantuan tidak terjadi saling berbagi pengalaman, tidak saling berinteraksi satu dengan yang lainnyadan tidak saling bekerjasama dalam menjalankan usaha. Dengan kata lain, tidak terjadi hubungan sosial diantara penerima bantuan untuk saling bekerjasama dan berbagi pengalaman dalam mengembangkan modal sosial yang mereka miliki masing-masing yang sebenarnya apabila dilaksanakan dapat meningkatkan ekonomi pelaku usaha yang difasilitasi oleh SKPD. Jika program kegiatan yang diprogramkan oleh setiap SKPD dapat berjalan selaras/sesuai antara acuan juklak juknis dengan prakteknya, maka program kegiatan
SKPD menjadi lebih berhasil dan bermanfaat baik bagi SKPD yang terlibat maupun bagi masyarakat sebagai penerima sasaran program kegiatan. Namun jika tidak, tentunya akan memperoleh hasil dan manfaat yang sebaliknya.

Praktek kegiatan yang terjadi seperti yang telah dikemukakan di atas, diakibatkan oleh tidak jelasnya informasi yang diterima, diikuti pula dengan data yang kurang akurat dan fakta di lapangan.

Berkaitan dengan informasi yang didapat, diketahui bahwa penerapan aksi dari program PM2L dikembalikan kepada SKPD masingmasing. Oleh karena itu, untuk menjamin implementasi program dalam era reformasi dan otonomi daerah supaya dapat berjalan dengan baik dan konsekwen, maka bagi pihak atasan harus mempertimbangkan rotasi dan mutasi pegawai, menempatkan pegawai yang terpilih dan mampu menterjemahkan aturan di bidang tugasnya. Begitu pula dengan aparat pelaksana SKPD, guna meminimalisir terjadinya kecurangan akan menjadi lebih baik. Seyogyanya pelaksana memberi laporan kegiatan 
yang sebenarnya menyangkut realisasi dan hambatan program kegiatan dengan mengedepankan transpransi dan kejujuran dengan didukung oleh data yang akurat dan fakta yang terjadi di lapangan.

Pembinaan ; Tidak Dilaksanakan Karena Alasan Anggaran

Pembinaan kegiatan

seharusnya dilakukan oleh masingmasing SKPD di kabupaten, namun ternyata sebagian besar SKPD tidak melaksanakan pembinaan, bahkan masyarakat yang diberi bantuan terkesan diacuhkan begitu saja. Hal tersebut dikarenakan terdapat kendala-kendala yang terjadi di lapangan, seperti yang dikemukakan oleh Pak Arsiles dari Dinas Perkebunan Provinsi Kalimantan Tengah bahwa salah satu kendala dalam pembinaan adalah tidak tersedianya dana dari pihak kabupaten untuk kegiatan tersebut. Hal ini mengakibatkan SKPD-SKPD pelaksana di kabupaten kurang memiliki greget untuk melakukan pembinaan di desa penerima PM2L. Sementara pihak Pemerintah Provinsi sudah melakukan koordinasi dengan SKPD-SKPD di Kabupaten.
Ada dua tahapan yang bisa dilakukan oleh SKPD ketika melakukan pembinaan terhadap penerima bantuan di desa PM2L. Pertama dilakukan ketika barang bantuan modal/usaha didistribusikan. Tahap ini merupakan pembinaan teknis berupa pemberian bimbingan/pelatihan tentang bagaimana menjalankan kegiatan/usaha yang difasilitasi oleh SKPD. Tahap pembinaan berikutnya adalah ketika tahap monitoring sudah dilaksanakan oleh pelaksana teknis ataupun yang ditugaskan untuk melalukan hal tersebut. Dalam pelaksanaan pemantauan (monitoring) ditemukan permasalahan yang perlu penanganan, yaitu menyangkut pelaksanaan secara teknis dan keberlanjutan program. Dengan terdeteksinya permasalahan sedini mungkin, diharapkan dapat segera dilakukan pembinaan oleh SKPD yang menangani tugas pokok dan fungsi yang sesuai dengan permasalahan yang ditemukan di lapangan.

Dari hasil temuan didapatkan bahwa pembinaan yang seharusnya dilaksanakan oleh SKPD tidak 
dilaksanakan sesuai dengan

pendamping tersebut hanya ketentuan karena terdapat faktor mendampingi, bukan membina. penghambat seperti tidak tersedianya dana sharing untuk pembinaan ke desa lokasi PM2L oleh SKPD kabupaten. Sementara itu, kewenangan pembinaan lanjut tidak sepenuhnya lagi menjadi tanggung jawab SKPD provinsi namun sudah diserahkan kepada SKPD kabupaten. Namun dalam pelaksanaannya, sebagian SKPD kabupaten tidak melakukan pembinaan awal bahkan tidak pernah sama sekali melakukan pembinaan berupa pemberian bimbingan/ pelatihan untuk pelaksanaan kegiatan, begitu juga dalam hal melakukan pembinaan lanjut.

Akibat dari tidak adanya pembinaan dari pihak SKPD yang memberi bantuan adalah masyarakat merasa ditinggalkan dan terkesan diacuhkan begitu saja serta tidak merasa bertanggung jawab dalam menjalankan dan menyukseskan program kegiatan yang difasilitasi SKPD. Sementara itu, pihak SKPD beranggapan bahwa cukup SM2L ataupun PPL saja yang melakukan pembinaan di Desa Lokasi PM2L. Padahal tugas dari para tenaga Mendampingi dalam arti jika terdapat permasalahan yang terjadi dari penerima bantuan, para tenaga pendamping tersebutlah yang bertugas memberi solusi maupun menanganinya. Menurut Sumardjo (2010) Peran penyuluh sebagai pemberdaya bagi masyarakat tradisional sebagaimana dikemukaan adalah : 1) Membangkitkan kebutuhan untuk berubah; 2) Menggunakan hubungan untuk perubahan; 3) Mendiagnosis masalah; 4) Mendorong motivasi untuk berubah; 5) Merencanakan tindakan pembaharuan; 6) Memelihara program pembaharuan dan mencegah stagnasi; 7) Mengembangkan kapasitas kelembagaan; dan 8) Mencapai hubungan terminal untuk secara dinamis mengembangkan proses perubahan yang lebih adaptif terhadap perubahan lingkungan.

Berdasarkan temuan, ternyata ada tahapan pemberdayaan yang terputus menyangkut pembinaan dan pelestarian. Sehubungan dengan hal tersebut berdasarkan konsep pemberdayaan yang dikemukakan 
menurut Randy \& Riant (2007) bahwa pemberdayaan adalah proses menjadi dan bukanlah proses yang sifatnya instan. Dimana proses tersebut memiliki tahapan-tahapan yaitu berupa tahapan penyadaran, pengapasitasan dan pendayaan. Sementara penelitian serupa yang dilakukan oleh Wilson (1996) juga mengemukakan bahwa tahapan pemberdayaan terdiri dari penyadaran, pemahaman, pemanfaatan dan penggunaan.

\section{Berdasarkan}

beberapa

pendapat yang telah dikemukakan, sekiranya pelaksanaan terkait dengan pemberdayaan perlu ditambahkan tahapan pembinaan dan pelestarian, sehingga diharapkan tidak ada tahapan atau proses yang terputus (miss link). Jadi, tahapan pemberdayaan menyangkut pemberian bantuan yang sifatnya stimulus untuk merangsang usaha ekonomi rakyat melalui pelaksanaan program kegiatan birokrasi dimulai dari tahapan penyadaran, kemudian tahapan pemahaman, dilanjutkan dengan tahapan pembinaan, kemudian tahapan penggunaan, tahapan pemanfaatan, dan tahapan terakhir berupa tahapan pelestarian.

Monitoring; Saling Mengandalkan Antara SKPD dengan SM2L

Proses

masyarakat yang harus selalu dilaksanakan tiap periode tertentu adalah monitoring. Monitoring bertujuan mendapatkan umpan balik bagi kebutuhan program yang sedang berjalan. Dengan mengetahui kebutuhan apa saja yang masih belum terpenuhi, maka pelaksana program dapat segera mempersiapkan kebutuhan tersebut. Kebutuhan bisa berupa biaya, waktu, personel, maupun peralatan. Pelaksanaan program akan mengetahui berapa biaya yang dibutuhkan, berapa lama waktu yang tersedia untuk kegiatan tersebut. Dengan demikian akan diketahui pula berapa jumlah tenaga yang dibutuhkan, serta alat apa yang harus disediakan untuk melaksanakan program tersebut.

$$
\text { Proses monitoring dalam }
$$
pelaksanaan PM2L masih belum maksimal dilakukan oleh aparat terkait, namun monitoring yang dilakukan selama ini lebih mengharapkan kepada laporan kepala desa, laporan SM2L dan laporan tenaga lapangan yang 
merupakan perpanjang tangan dari setiap SKPD (PPLKB, PPL pertanian/peternakan, PSM) yang kebetulan secara penugasan ditempatkan di lokasi desa PM2L. Akan tetapi, petugas lapangan dari SKPD yang terlibat tidak terdapat di semua desa lokasi PM2L. Jadi selama ini monitoring kegiatan PM2L hanya dilakukan oleh petugas lapang yang ditempatkan di desa tersebut, sementara monitoring secara langsung dari aparat SKPD yang mempunyai kegiatan atau staf teknis secara keseluruhan hampir tidak pernah dilakukan oleh aparat SKPD baik dari provinsi maupun kabupaten.

Nihilnya monitoring dari aparat SKPD terkait dikarenakan kendala anggaran yang terbatas, apalagi mengingat lokasi desa PM2L pada umumnya letaknya sangat sulit untuk dijangkau. Hal tersebut terindikasi dari tidak adanya sebagian laporan pelaksanaan tugas dari petugas provinsi maupun kabupaten yang bisa disajikan ketika diminta oleh peneliti. Disamping itu, sebagian dari aparat tidak mengetahui secara benar hasil dan manfaat serta perkembangan kegiatan yang telah difasilitasi oleh SKPD yang bersangkutan karena alasan baru menjabat dan lain sebagainya.

Monitoring seharusnya dilakukan oleh SKPD Provinsi dan kabupaten secara bersama-sama selama 4 hari di seluruh lokasi desa PM2L. Namun pada kenyataannya, pihak provinsi tidak dapat melakukan monitoring ke seluruh desa PM2L dikarenakan waktu yang dialokasikan terlalu pendek, sehingga tidak semua lokasi desa PM2L dapat dikunjungi. Oleh karena itu, pihak kabupaten sebagai perpanjangan dari pihak provinsi difasilitasi untuk melakukan monitoring selanjutnya ke desa-desa lokasi PM2L tersebut karena kabupaten/kota lah yang punya wilayah.

Berdasarkan dari pernyataan tersebut dengan waktu yang sangat singkat dan dana yang terbatas tidak mungkin monitoring dilaksanakan sesuai dengan aturan dan juga dimungkinkan petugas tidak sampai ke lokasi yang seharusnya secara keseluruhan, sehingga seringkali monitoring dilakukan hanya pada desa sample saja. Sementara 
anggaran yang diambil untuk melakukan monitoring tersebut adalah dari dana dekon (APBN) dan dari dana APBD, namun anggaran monitoring untuk SKPD provinsi tidak setiap tahun ada, walaupun terkadang ada di tahun ke 2. tetapi tidak bisa dilaksanakan Hal tersebut terkendala oleh adanya pemotongan anggaran, sehingga seringkali kegiatan monitoring tidak dilaksanakan oleh pihak provinsi. Sementara itu ketentuan untuk membuat laporan monitoring tergantung dari pelaksana. ada yang melampirkan foto ada juga yang tidak, karena alasan dananya tidak tersedia di anggaran kegiatan.

Realisasi anggaran yang tidak sesuai juga merupakan permasalahan dalam melakukan monitoring pihak provinsi ke lokasi desa PM2L. Misalkan dana yang tersedia di POK atau DPAnya untuk melakukan perjalanan dinas hanya tersedia satu juta, namun ternyata pengeluarannya untuk melakukan perjalanan dinas sampai ke desa tujuan dana yang dikeluarkan melebihi anggaran yang tersedia. Oleh sebab itu, monitoring di tempat lokasi PM2L seringkali tidak bisa dilaksanakan ke semua lokasi desa PM2L terkendala biaya yang cukup besar ke lokasi.

Seperti apa yang telah diuraikan sebelumnya bahwa tidak semua SKPD melakukan monitoring secara langsung ke lokasi PM2L, tapi menyerahkan tugas tersebut kepada SM2L dan PPL di lapangan. Sementara itu, mengenai informasi ada tidaknya pemantauan yang dilakukan oleh SKPD, setelah dicrosscek kepada masyarakat ditemukan bahwa memang pihak SKPD tidak pernah melakukan monitoring ke desa lokasi penelitian. Masyarakat yang lainpun juga mengatakan hal demikian, baik di Desa Kandan maupun Desa Bagendang Tengah. Hal tersebut mengindikasikan bahwa memang monitoring tidak pernah dilakukan di desa penerima PM2L yang menjadi lokasi penelitian, sehingga prinsip sinergisitas antar SKPD propinsi maupun SKPD kabupaten maupun antar SKPD yang menjalankan kegiatan yang sifatnya sejenis dalam pelaksanaan PM2L selama ini belum sepenuhnya terpenuhi. Tidak bersinergisnya kegiatan SKPD propinsi dan kabupaten maupun SKPD yang menjalankan kegiatan 
yang sifatnya sejenis tersebut dilihat dari pihak SKPD kabupaten tidak menyediakan anggaran sharing untuk melakukan monitoring kegiatan SKPD propinsi.

$$
\text { Meninjau fungsinya, }
$$

monitoring pada dasarnya dilakukan untuk mengukur hasil yang sudah dicapai dalam melaksanakan program dengan alat ukur rencana yang sudah dibuat dan disepakati. Selain itu, analisa dari semua hasil pemantauan (monitoring) dapat dijadikan bahan dalam mempertimbangkan keputusan serta usaha perbaikan dan penyempurnaan untuk kegiatan selanjutnya. Namun hasil yang diperoleh dari penelitian ini dapat dipaparkan bahwa tidak dilaksanakannya monitoring dalam PM2L, berarti tidak terpenuhi pula fungsi monitoring yang seharusnya dapat mengukur dan menganalisis pelaksanaan program PM2L di lapangan guna memperbaiki pelaksanaan program dan menyelesaikan permasalahan PM2L yang terjadi di lapangan.

\section{Evaluasi ; Berorientasi pada Realisasi Fisik dan Penyerapan Keuangan}

Sebagai tahap akhir dari pelaksanaan kegiatan yang dilakukan oleh setiap SKPD, langkah selanjutnya dilakukan penilaian atau evaluasi program kegiatan yang telah dilaksanakan pada tahun berjalan. Evaluasi bertujuan memperoleh informasi yang tepat sebagai bahan pertimbangan untuk mengambil keputusan tentang perencanaan program, keputusan tentang komponen input pada program, implementasi program yang mengarah kepada kegiatan dan keputusan tentang output menyangkut hasil dan dampak dari program kegiatan.

Akan tetapi evaluasi yang dilakukan pihak SKPD kabupaten tidak menyediakan dana sharing untuk evaluasi, hampir semua SKPD pada umumnya hanya menilai realisasi fisik dan keuangan yang terserap pada tahun berjalan tersebut dan masih belum sampai kepada penilaian hasil kinerja secara fungsional kegiatan. Dalam arti, evaluasi yang dilakukan belum sampai melihat kepada hasil dan manfaat kegiatan tersebut dikerjakan oleh penerima secara berkelanjutan. 
Selaku pihak yang mempunyai kewenangan untuk mengkoordinir kegiatan PM2L BAPPEDA tidak melaksanakan evaluasi sampai ke tahap pelaksanaan kegiatan menyangkut hasilnya, karena hal tersebut sudah merupakan kewenangan dari masingmasing SKPD untuk melakukan evaluasi kegiatannya masing-masing. Dan pihak BAPPEDA mengevaluasi hanya sebatas merekap realisasi anggaran yang didasarkan atas rencana aksi SKPD yang terlibat, dan hanya menghimpun laporan pelaksanaan kegiatan yang dilakukan oleh setiap SKPD tersebut, akan tetapi tidak semua SKPD menyampaikan laporan pelaksanaan kegiatannya ke pihak BAPPEDA menyangkut PM2L.

Menyangkut realisasi aksi kegiatan SKPD berdasarkan rencana aksi bersama, pada awlanya rencana anggaran cukup besar, tetapi setelah adanya rasionalisasi, kegiatan PM2L bukan lagi menjadi prioritas sehingga dananya hilang atau terpotong, dan kegiatan tidak terealisasi. Selain itu menyangkut pemahaman aparat menurut pihak BAPPEDA bahwa tidak semua aparat SKPD yang terlibat dalam perencanaan mengerti apa yang dinamakan outcome, akibat kurangnya pemahaman dari pihak aparat yang tidak serius dalam menjalankan tupoksinya, sehingga ketika memprogramkan kegiatan kepada masyarakat tidak benar-benar berdasarkan kebutuhan dan hanya sekedar semacam unsur kewajiban, setelah dilaksanakan tidak ada follow-upnya (tidak ada tindak lanjutnya). Sementara masyarakat hanya menunggu dan tidak ada inisiatif kreatifitasnya, artinya untuk merubah hidupnya lebih baik tidak tahu bagaimana menyambutnya. Sedangkan menurut SKPD yang terlibat menyatakan bahwa belum optimalnya PM2L dikarenakan staf pelaksana itu tidak semua memahami bidang tugasnya, karena ada yang sebagian pegawai baru, dan belum lagi sering terjadi mutasi pegawai. Atas dasar tersebut akan diketahui kendala-kendala yang dihadapi dan akan menjadi bahan perbaikan kegiatan selanjutnya yang dikoordinir oleh pihak BAPPEDA.

Berdasarkan dari fenomena yang terungkap, menunjukkan bahwa evaluasi yang dilakukan oleh hampir 
semua SKPD masih berorentasi kepada masukan (input) dan keluaran (output) secara realisasi penyerapan keuangan dan kegiatan saja. Evaluasi yang dilakukan hanya melihat dari realisasi fisik dan keuangan, dan masih belum mengevaluasi kegiatan sampai kepada hasil (outcome) dan manfaat (benefit) pelaksanaan kegiatan. Tingkat kesungguhan aparat untuk memprogramkan kegiatan belum secara sungguhsungguh untuk menyukseskan program Hal tersebut dikarenakan hampir semua aparat SKPD yang terlibat dalam perencanaan tidak mengerti apa yang dinamakan outcome.

Indikasi tersebut terlihat dari hampir semua SKPD yang terlibat tidak mempunyai kemampuan untuk menyajikan data keberhasilan dan ketidakberhasilan pelaksanaan kegiatan yang telah dilakukan pada tahun-tahun sebelumnya. Dengan terakumulasinya data kegiatan yang bisa ditampilkan misalnya jumlah kegiatan yang masih berjalan, sudah mandiri ataupun yang terhenti sama sekali, maka akan dapat diketahui indikator tingkat keberhasilan kinerja SKPD yang bersangkutan dalam melayani masyarakat. Dengan demikian, tingkat keberhasilan pelaksanaan pembangunan berupa memberdayakan masyarakat secara ekonomi akan dapat terbangun. Tidak hanya ditentukan oleh kemampuan masyarakat yang menjadi obyek dan subyek kegiatan saja, melainkan juga tergantung dari SKPD yang memfasilitasi kegiatan tersebut dengan menempatkan orang yang tepat dan mampu di dalam menjalankan bidang tugasnya baik secara teknis maupun administrasi.

Dari hasil penelitian di lapangan secara evaluasi bahwa ketidakmampuan seorang pelaksana ataupun aparat pemerintah dalam menjalankan tugasnya dikarenakan beberapa faktor berikut:

1. Penempatan aparat yang bersangkutan tidak sesuai dengan keahlian dan kemampuannya atau dengan kata lain penempatan yang dilakukan pada suatu bidang teknis asal saja tanpa memperhatikan kemampuan seseorang dan cenderung hanya dilihat dengan tingkat kepangkatan/ golongan ruang 
seseorang untuk memenuhi posisi tersebut.

2. Seringnya terjadinya rotasi dan mutasi pegawai pada tahun berjalan ketika rencana kegiatan dan anggaran sudah ditetapkan yang pada akhirnya mempengaruhi kesadaran dan kemampuan dari aparat yang bersangkutan untuk mengusai bidang teknisnya.

3. Tidak tersedianya indikator penilaian kinerja aparat pemerintah yang mampu memberikan rasa keadilan dalam menjalankan tugas dan tanggungjawabnya secara profesional.

4. Ketidakmampuan aparat untuk menterjemahkan kewenangan di bidang tugasnya, hal ini terkait dalam menjalankan kegiatan yang sifatnya sejenis yang membutuhkan koordinasi, sinergisitas dan sinkronisasi antar SKPD.

Untuk mendapatkan suatu hasil yang baik dalam pembangunan tentulah membutuhkan orang-orang yang terbaik dan terpilih pula, sebab untuk memberdayakan orang lain alangkah baiknya aparat yang diberikan amanah untuk melalukan hal tersebut dibekali dengan ilmu pengetahuan tentang bagaimana untuk memberdayakan dirinya terlebih dahulu sebelum memberdayakan orang lain. Dengan kata lain, persiapkan senjata dan peluru yang ampuh berupa penguasaan dan pemahaman di bidang tugasnya sebelum melaksanakan aksi. Sebab upaya untuk pemberdayaan masyarakat secara ekonomi harus dilakukan atas dasar kesadaran, kemampuan, potensi, maupun sumberdaya yang ada dan sesuai kriteria, serta dengan tidak meninggalkan budaya (kearifan lokal) masyarakat setempat.

\section{KESIMPULAN}

Dalam implementasi PM2L terdapat beberapa tahapan yang harus dilalui yaitu tahapan koordinasi, sosialisasi, penerapan aksi, pembinaan, monitoring dan evaluasi. Secara garis besar tahapantahapan yang dilalui dalam implementasi program belum optimal dalam pelaksanaannya, terlebih dalam hal tahapan pembinaan. Tahapan impementasi 
PM2L yang ditemui di lapangan antara lain:

1. Dalam tahap koordinasi, kegiatan yang dilakukan memang tidak terjadi tumpang tindih, namun masih belum terjadi sinkronisasi kegiatan.

2. Dalam tahap sosialisasi, ternyata sosialisasi hanya dilakukan sampai pada level pemerintah desa dan belum ke masyarakat sasaran.

3. Dari penerapan aksi yang dilaksanakan tenyata banyak terjadi penyimpangan terhadap aturan, baik oleh SKPD maupun masyarakat.

4. Tahap pembinaan tidak dilaksanakan dengan dalih tidak tersedianya anggaran untuk pembinaan dari pihak kabupaten

5. Dalam tahap monitoring, SKPD dan SM2L saling mengandalkan dalam memonitoring penerima bantuan PM2L

6. Dalam tahap evaluasi, berorientasi pada realisasi fisik dan penyerapan keuangan saja, belum sampai kepada penilaian hasil kinerja secara fungsional kegiatan

\section{Saran}

Seluruh tahapan dalam, implementasi aksi program kegiatan PM2L masih perlu dimantapkan, runtut dan disesuaikan dengan kondisi atau linear dalam pelaksanaannya.

\section{DAFTAR PUSTAKA}

Banteng, Sugih Arto. 2004. Partisipasi Masyarakat dalam program Perencanaan Program PEMP di Kabupaten Bolaang Mangandow. Tesis Magister yang Tidak Dipublikasikan. Program Pasca Sarjana UGM. Yogyakarta.

BPS (Badan Pusat Statistik) Propinsi Kalimantan Tengah. 2010. Kalimantan Tengah Dalam Angka 2009. Palangkaraya.

BPS (Badan Pusat Statistik) Propinsi Kalimantan Tengah. 2010. Penduduk Miskin (Poor Population). Palangkaraya.

Haris, Syamsuddin (Ed.). 2007. Desentralisasi, Demokratisasi \& Akuntabilitas Pemerintah Daerah. Edisi Ketiga. LIPI Press. Jakarta.

Kuncoro, Mudrajad. 2006. Ekonomika Pembangunan : Teori, Masalah, dan Kebijakan. Penerbit UPP STIM YKPN d/h AMP YKPN. Yogyakarta.

Moleong, Lexy. 2006. Analisa Data Kualitatif. Bandung. Remaja Rosda Karya. 
Mubyarto. 2002. Pemberdayaan

Ekonomi Rakyat dan Peranan

Ilmu-ilmu Sosial. Yayasan Agro-Ekonomika.

Yogyakarta.

Randy. R, dan Riant N. Dwidjowijoto, 2007. Manajemen Pemberdayaan : sebuah pengantar dan panduan untuk pemberdayaan masyarakat. PT. Elex Media Komputindo. Jakarta.

Sumardjo. 2007. Metoda Partisipatif dalam Pengembangan Masyarakat. Magister Profesional Pengembangan Masyarakat. Sekolah Pascasarjana IPB. Bogor.

Sumardjo. 2010. Revitalisasi Peran Penyuluh Sosial dalam
Penyelenggaraan

Kesejahteraan

Sosial.

Makalah disampaikan

Konggres I Penyuluh Sosial pembinaan pejabat fungsional penyuluh sosial. Jakarta 1920 Mei 2010.

Sumaryadi, I Nyoman. 2005. Perencanaan Pembangunan Daerah Otonom dan Pemberdayaan Masyarakat. Penerbit Citra Utama. Jakarta.

$\begin{array}{cr}\text { Usman, } & \text { Sunyoto. } \\ \text { Pembangunan } & \text { dan } \\ \text { Pemberdayaan } & \text { Masyarakat. } \\ \text { Pustaka Pelajar. Yogyakarta. }\end{array}$

Wilson, Terry. 1996. The Empowerment Mannual. Grower Publishing Company. London. 